\title{
Original Contributions of Physicians During the Islamic Era
}

\author{
Farid Sami Haddad, MD, FACS \\ Phoenix, Arizona
}

DOI: http://dx.doi.org/10.5915/28-3-5530

$\mathbf{T}$ he Islamic Era starts with the "Hijrâh," or emigration, of Prophet Muhammad [PBUH] in 623 and ends in 1492, the year of the downfall of Granada and the year Columbus sailed in search of the New World. The Islamic Era under consideration therefore spans 870 years. The greatest intensity of medical contributions occurred between 800 (the date of the first contribution) and 1400 (the date of the last contribution by al-Qalqashandi), a period of 600 years.

Up to the year 1200 , there lived at least 400 famous physicians. At least 4,000 medical books were written during the Islamic Era, which have to be studied before we can enumerate the contributions of the physicians.

These books of medicine all were written in Arabic. For nine centuries, from Bihär, in the east, to Morocco, in the west, Arabic replaced Greek as the means of international communication and became the universal language of science and medicine, as English is in our time. Anyone who aspired to become a physician in any part of this vast intellectual Islamic empire learned medicine in books written in Arabic. For example, the Christian Hunin ibn 'Ishāq (Johannitus), the Persian al-Rāzi, and the Spaniard Rabbi ibn Maymūn (Maimonides) wrote in Arabic. Just as young physicians from all parts of the world flock today to the United States, so did the young physicians in the Islamic Era flock to Baghdad, Cairo, or Damascus for postgraduate training or to open a practice.

Even beyond the Islamic Era, in the 16 th and 17 th centuries, anyone aspiring to become a physician had to be

From the Department of Surgery

University of Arizona

Tuscon, Arizona

Reprint requests: Farid Sami Haddad, MD, FACS

4332 E. Piccadilly Road

Phoenix, AZ 85018 proficient in Arabic. We know, for example, that the Belgian Vesalius (1514-1564) and the Englishman Harvey (1578-1657) had to Iearn Arabic in order to dip into the treasured heritage of Arabic medicine.

\section{Sources}

The main sources of this study can be grouped under two headings: texts of Arabic medical manuscripts and more recent reference books and articles.

First and foremost come the texts of the books the physicians have written during the Islamic Era. Arabic medical literature is so unbelievably vast and extensive. We do not know the exact number of medical books written during the Islamic Era, but we know it was very large. For example, the library of the "Mustanșiriyyah" at the University in Bagdad contained 80,000 volumes. ${ }^{\text {ta }}$ The library of Cordoba at the time of al-Hakam (796-831) contained 600,000 volumes, and its catalog alone made up 44 volumes. The Fatimid library of Cairo contained 2 million volumes. The library of Tripoli, which was burnt by the crusaders, had 3 million volumes. The Baghdad libraries in the 13th century contained so many books that Hulago was able to use them to make a bridge across the Tigris River for his hordes to cross over.

Ibn-ul-Mutrann (d. 1191), the famous Damascene physician who served Saladin, had two full-time scribes in his house who copied books for him. When he died, he left a library estimated to be more than 13,000 volumes. Another famous physician had $\mathbf{4 0}$ scribes who copied books for him. A rough estimate is that the number of important medical books written during the 870-year Islamic Era is about 4,000 . The beauty of these books is that, with exceedingly rare exceptions, they all are referenced with great care and detail.

If all these books still were available and if one were to spend a lifetime reading them at the rate of one book a week, it would take 80 years just to read them all, to say nothing about studying them. Unfortunately, only a small portion 
of these books is known 10 have survived the devastating havoc of the intervening centuries.

Some of these books have come down to us either in their original form or in Latin translation. Unfortunately, the bulk of what remains from this rich and valuable heritage has nol yet been translated and is still therefore unobtainable except in Arabic and mostly in the form of manuscripts.

The Arabic medical manuscripts that were lucky to have survived all these years are estimated to be about a thousand. They are scallered all over the world; some are stored in the great libraries, like the Bibliotheque Nationale in Paris, the British Museum in London, the Beatty collection in Dublin; and other great repositories of Arabic medical manuscripts in Cairo, Istanbul, Damascus, Munich, Milano, Boston, Washington, New York, Rome, Bologna, and Cleveland, Ohio. Other Arabic medical manuscripts remain hidden in lesser known and smaller collections, which often have no printed catalog. The location of still others remain, for all practical purposes, unknown. Perhaps, fewer than a 100 of these remaining manuscripts have been printed so far and a smaller number have been translated into modern languages.

My late father, Dr. Sami I Haddad (1890-1957), who was professor of surgery at the Medical School of the American University of Beirut, was interested in the history of Arabic medicine. He studied the subject in his spare time and wrote several articles about it, most of which were published in Arabic, some in English, and one in French. Starting in 1930, he collected more than 400 Arabic manuscripts, of which 123 of them were about medicine. He tended them with great care. He had a special bookcase built for them from carved walnut.

In 1984, I published, with H.H. Biesterfeldt from Germany, a catalog of medical manuscripts found in my father's library. ${ }^{2 a}$ Before this catalog was published in 1984, these 123 Arabic medical manuscripts were practically unknown except to a handful of scholars. There are hundreds of similar private libraries with contents that are still unknown. New catalogs of Arabic medical books are being published constanily. As a consequence, our knowledge of the contributions of the physicians during the Islamic Era is continuously expanding. Still, what we know today is only a very small fraction of the total contribution.

Until very recently, I had no knowledge of the great and numerous contributions of the famous Andalusian physician ibn Zuhr. In 1983, his book "al-Taysir" was published for the first time in Damascus. When a copy of this edition became available to me, ${ }^{3} \mathrm{I}$ avidly read and became fascinated with the clarity of expression, the width of the vista, and the wealth of the contributions of ibn Zuhr.

The contributions of physicians are, for the most part, buried in Arabic manuscripts and in Latin translations awaiting discovery. The contributions that I could glean for you from the available literature represent only a very small frac- tion of the contributions to be found in the Arabic medical literature.

The second source is the reference works left by eminent historians, both in Arabic and in modern European languages, and the numerous articles written on the subject by a string of historians from every country and every continent who have diligently and reverently studied the works of our noble forebears. ${ }^{4-5,66,7-15}$

Preeminent among all of these references is undoubtedly the great work of the famous historian of Arabic medicine who lived in "Sal Jad," in "Jabāl-ul-Durūz." This is the famous ibn 'Abi 'Usaybi 'ah who wrote in 1257 the book entitled "Uyiun al-'Anbā' fi Tabagāi nl-'Atibbä"' (The Sources of Information about the Categories of Physicians). ${ }^{\text {ti }}$ It contains the biographies of more than 400 physicians who were famous in the "Mashriq" (East) and in the "Maghrib" (West). The book is a fascinating and bottomless treasure of information about these physicians, the books they wrote, and the diseases they treated, as well as their stories, anecdotes, and poetry.

\section{Contributions by Nonphysicians}

If I were to stick strictly to the first term of the litle, we would miss the important contributions made to medicine, directly or indirectly by nonphysicians. In order to complete the picture, I will cite two great and important nonmedical contributions made by nonphysicians.

The first was a Hadith of the Prophet Muhammad [PBUH]: "Seek the knowledge even if it were in China." The effect of this saying has been far reaching. Since that time, students of medicine traveled, and still travel far and wide, in the pursuit of medical knowledge. In the Islamic Era, no matter where one came from, it was imperative to seek knowledge in the city. Students flocked to the great centers of learning, such as Damascus, Baghdad and Cairo, and later the Andalusian centers such as Cordoba and Seville. There are many examples of traveling in pursuit of learning, but I shall cite only two.

One of the first examples was that of "al-Harith ibn Kablah al-Thaqafi," the Prophet's cousin, who traveled to Gundishapur for medical study and whose medical course was crowned by his famous and most successful interview with Chosroe II who admired his ready wit and his intelligence. This interview has been recorded in the history books. The second example is that of "ibn al-Bitär" who traveled from Malaga in Andalusia, across "Jabal Tăariq" (Gibraltar) to Tangiers, North Africa, Egypt, and Damascus, all the way collecting medicinal herbs for his famous and encyclopedic book. ${ }^{16}$ This migration in pursuit of learning has become a tradition still followed today.

The migration of the father of the DeBakey brothers from "Judaydát Mari ūn," a small town in Syria, to the United States, ${ }^{17.19}$ and the migration of Dr. George Hatem (1910-1989) from another small town "Hammānā" (named after Hammon the Phoenician god of warmth or the sun 
god) in Lebanon 10 become Mae Haide, the prime architect of public bealth reform in Mao's China.

The second imporlant contribution made by a nonphysician is of a slightly different nature, and was the result of the astuteness of Caliph 'Umar. Following the famous battle of Khaybar (628), Caliph 'Umar devised a new institution or system called "Waqf," (an endowment or trust) a foundation for the poor, the slaves, and the travelers, and endowed it with some domains he acquired at the battle with the definite prescription that these domains should neither be sold nor transmitted by inheritance. ${ }^{20}$

This precedent has been followed all the way from the time of 'Umar until the present. Anyone can put in perpetual and irrevocable trust property onc possesses, the fruits of which are to be used for lofty and charitable purposes, which the contributor prescribes in the waqf deed. This instifution has had widespread influence on all aspects of Islamic civilization. Innumerable funds and estates thus became available for the erection, administration, and maintenance of insumerable charilable institutions, such as mosques, schools, and, more specifically, hospitals for the sick and poor. ${ }^{20}$ The waqf is the precursor of the modern endowment and trust system. We may think of it as being a new tool in financial management.

Under this regime, "Bimăristans" (hospitals) were built with wagfs in 44 cities, ${ }^{21} 13$ were built in Baghdad, 9 in Cairo, 7 in Damascus, 5 in Aleppo, and 1 in Mecca, Medinah, Mosul, Alexandria, Hama, Antioch, Jerusalem, Nablus, Gaza, Acre, Fez, Cordoba, Granada, Marrakesh, Tunis, Isfahan, Shiraz, Tabriz, Rayy, Istanbul, Edirne, Konya, Bursa, and Samarkand. All of them were so richly endowed that all of their services were rendered free of charge. The hospital built in 1156 not very far from the Umayyad Mosque by the benevolent ruler of Damascus, the Turkish "Nür-iddin al-Zinki," is still standing and is being used as a museum. Others are in ruins; still others have literally disappenred.

The site on which the hospital was to be built was chosen very carefully. It is said that when al-Razi was asked to give advice on a site for a proposed bospital to be built in Baghdad, he sent out several of his men to hang half a sheep's carcass in each quarter of the city; he regularly inspected the carcasses for any sign of decay. That site where the meat showed the least amount of deterioration and putrefaction and where de process of change was the least rapid. was indicaled as the favored site. ${ }^{6 b}$

When al-Manșūr dedicated his hospilal in Cairo, he said: "I dedicate this hospital to my peers, and to my inferiors. I constitute this waqf for the benefit of the master and the subject, the soldier and the general, the great and the small, the free man and the slave, for men and for women."22a

These hospitals were well organized and well run. It behooves us to study their establishment, their management. and their growth as a model for the present day health care system, which is oscillating between the greod of the finan- ciers, the nonchalance of the medical profession, and the ignorance and gullibility of the people.

Numerous medical schools with a prescribed medical curriculum, clinical apprenticeship (today's residency), medical licensure, and various forms of clinics such as ambulatory clinics and clinics for the prisons were established during the Islamic Era. Most of the hospitals had their own medical schools, but there were also several private medical schools.

These were two important contributions made by nonphysicians. There are several others, but I will only mention the contribution of a relatively late bistorian, alQalqashandi, from Cairo, who was the earliest to refer to sleeping sickness in his encyclopedic book, "Subh al'A'shā," around 1418. The thought that the carliest reference to sleeping sickness was made by the British Naval surgeon Atkins in 1721 is no longer tenable; al-Qalqashandi made his observation 300 years earlier. In the English translation al-Qalqashandi's text reads as follows: "The demise of the king of Mali was brought about by sleeping sickness which is a disease that frequently befalls the inhabitants of those countries, especially their governors, whereby sleep overtakes one of them in such a manner that it is hardly possible to awaken him. The sultan remained in this state for 2 years until be died in 775 (1373 AD)."23s

\section{Nonmedical Contributions by Physicians}

Although the contributions of physicians are, for the most part, medical in nature, there are numerous nonmedical contributions made by physicians.

Contributions were made to astronomy, carpentry, clocks, mathematics, and philosophy. ${ }^{23 \mathrm{k}}$ The referenced literature is replete with such examples. Original contributions were made to philosophy by “al-Fārabi" (873-950), Avicenna (980-1037), "ibn Bājā" (d 1138), "ibn Tufil Rushd" (1100-1185), "ibn Rushd" (1126-1198), and many others. In the long chain of international philosophers, these physicians who were also philosophers of the Islamic Era were the firm link between Plato, Aristotle, and the Greek philosophers, and the more modern European philosophers like St. Thomas Aquinas (1225-74), Bacon (1561-1626), Kant (1724-1804), Hegel (1770-1831), Auguste Comte (17981857), Whitehead (1861-1947), and Bertrand Russell (18721970).

The contributions to mathematics and mechanics of "Qustā ibn Lüqā," a famous physician from the city of "Ba'albak" (Lebanon), are well known. Thäbit ibn Qurrah translated the "Elements of Euclid." Ibn al-Muhandis made the famous gates of the "Nuri" Hospital in Damascus. Ibn al-Sā'āti was put on a monthly salary for attending to the sundial of the great mosque of Damascus.

Other contributions were made by physicians to other fields of study more intimately related to medicine: botany, chemistry, optics, physics, pharmacology and all its branches, zoology, and dentistry. Many physico-chemical 
processes were invented during the Islamic Era. They include calcination, crystallization, distillation, evaporation, filtration, precipitation, and sublimation. Many new chemical substances were first prepared during the Islamic Era. They include alcohol, aqua regis, hydrochloric acid, nitric acid, potash, sulphuric acid, and many others. ${ }^{23 n}$

\section{Original Medical Contributions by Physicians}

The bulk of the contributions of physicians during the Islamic Era were medical. These will be studied in two large sections: Original Medical Contributions and Contributions to Medical Literary Form. In the section on form, we shall take up the subject of versification of medical texts, illustration of medical texts, and the tabulation of medical and pharmacopeal information.

\section{Contributions to Anatomy}

Contributions to anatomy include:

1) The dissection of apes by Yuhannã ibn Māsawì (777-857). Unable to obtain human bodies, Yuhannā dissected apes in a special hall built on the banks of the Tigris. A particular species of apes, considered to resemble man most closely, was supplied to him by command of the Caliph al-Mu'tasim in about 836 by the ruler of Nubia. Ibn Massawih was not only the first physician in the Islamic Era to perform anatomical dissections, but he recorded his observations in a book, which has unfortunately been lost .

2) The first description of the laryngeal branch of the recurrent laryngeal nerve was given by al-Rāzi.

3) The mandible was a single bone and not two bones as was thought by the Greeks. This conclusion was arrived at after thorough examination of several hundred mandibles from a heap of bones found by al-Baghdadi in the vicinity of Cairo. ${ }^{23 \mathrm{a}}$

4) The description of the pulmonary circulation of the blood by ibn al-Nafis. The text of his discovery of the lesser circulation (the pulmonary circulation) is to be found in his "Sharh Tashrih al-Qamun" (Commentary on the Anatomy of the Canon). He contradicts Galen, who thought blood passed frons one side of the heart to the other through septal pores. He categorically affirmed that there were no pores in the cardiac septum, but that the blood goes from the right heart via the pulmonary artery to the lung, where it is acrated and purified in the alveoli to become fit for nourishment, and returns via the pulmonary veins to the left side of the heart. After the publication of the Latin version of ibn al-Nafis' book in 1547, several authors (Servet in 1553, Vesalius in 1553, and Colombo in 1559) described the pulmonary circulation in terms similar to ibn al-Nafis'. There is no doubt about the priority of ibn al-Nafis and about the fact that these three gentlemen must have copied from him. In fact, the first edition of Vesalius (1542) does not contain the discovery. Servet mentions the discovery in his "ristianismi Restitutio," a bio-religious book very similar to ibn al-Nafis' bio-religious book "al-Rajul alKämil" (The Perfect Man).

\section{Contributions to Medicine}

During the Islamic Era, several medical contributions were described for the first time; a partial list follows:

1) Peptic ulcer symptomatology described by Mãsarjawih. It is reported that one day when Mãsarjawih (c 800) was in his clinic examining the urine of his patients, there came to him a man from "Jūzistăn" complaining of a condition. The man said: "I wake up in the morning with blurred vision and I start to feel as if my stomach were being licked by a dog. This feeling persists until I eat something. When I eat something, this feeling disappears until midday when the feeling recurs; if I then eat again I am relieved until the sunset prayer when the feeling recurs and I can find no relief except by eating again."

Māsarjawih then said: "God made a mistake when he linked this disease to a lowly fellow like you. I would compensate you with half my property if this condition were to befall on me and on my children." The patient did not understand, so Māsarjawih told him: "What you are describing is nothing but real good health which you do not deserve. I am asking the Almighty to transfer it on to someone who is more worthy of it than you are." ${ }^{6}$ The Juzi patient was undoubtedly suffering from the hunger pains of early peptic ulcer so typically relieved by food. Although Mãsarjawih did not recognize it as such and thought it a sign of perfect health, it is nevertheless the first description of the symptoms of peptic ulcer in medical literature. Is it not befitting, therefore, to call peptic ulcer "The Jūzi Syndrome?"24

2) Pruritus due to food allergy described by ibn Māsawìh.

3) Dracunculus medinensis described by Qustā ibn Lüquā. ${ }^{2 s}$

4) Al-Rāzi described a patient by the name of 'Abū Zid al-Balkhi, the famous geographer, who had recurrent coryza in the spring when roses are in bloom. This is the first patient ever to be described with what we today think of as the modern disease of hay fever or allergic rhinitis, which could easily be surnamed 'abu Zïd al-Balkhi's disease." ${ }^{23 a}$

5) Al-Rāzi was also the first to differentiate between smallpox and measles, two diseases that were hitherto confused.

6) Al-Räzi also described neuropathic bladder caused by a tumor compressing the spinal cord in a patient named "Qaț̣̄n."26a

7) Scrotal gangrene (Fournier's Syndrome-1884) was described by al-Rázi who wrote: "I have seen in the hospital patients where all the skin covering the testicles (scrotum) was eroded and later fell off and nothing remained to cover the testicles which remained hanging from the cord, I treated these patients with sandal, rose, camphor and powdered diamond stone in the fluid extract of the common nightshade (Solanum nigrum) or gooseberry (Ribes glossularia). The flesh regrew into something hard but unlike the original scrotum. Nevertheless, it took its place and function and 
the patients were cured." 2 , 27, 28a This is a very clear and delailed description of scrotal gangrene given by al-Räzi almost 1,000 years before Fournier (1832-1914) attached his name to it. This condition should actually go by the name of "Rhazes Syndrome." A thousand years after Rhazes, Max Thorek did not improve on Rhazes description. In his recent book "The Human Testicle,"29 he says only this much about scrotal gangrene: "Randall encases the scrotum in gauze soaked in permanganate of potash solution .... when the wounds are clean, granulation commences and in time there is a new scrotum." $23 \mathrm{a}$

8) Al-Räi reported the case of a patient called "Amrawih" who developed a brain abscess following otitis media. ${ }^{28 b}$

9) The arthropod that causes scabies was described by A h.mad al-Tābāri in his "al-Mú alajat al-Buqratiyyah." Today it is called Sarcoptes scabiei.

10). Extra-uterine pregnancy was described by alZahrāwi (Albucasis). ${ }^{30}$

11) Placenta accreta was also first described by alZabrāwi. ${ }^{3 \text { เa }}$

12) Al-Zahráwi ${ }^{23 b, 30 n, 316}$ was not only the greatest Arab surgeon, but he was also the leading clinician who was the first to describe a sex-linked inheritable bleeding tendency which today is called hemophilia. ${ }^{32,32 b, 33}$

13) Al-Zahrāwi also described tuberculosis of the spine, which today is called Pott's disease.

14) Ibn Sinā (Avicenna) was the first to describe incompetence of the aortic valve.

15) Ibn Sina also described anthrax, which he called Persian fure.

16) Abū al-Farrajj reports the following history in a male slave of Greek origin who came from Constantinople with splenomegaly, bilious pallor, and frequent reddish urine. He was always thirsty and, in the course of his illness, he developed anorexia, then right hemiplegia, which improved within 10 days. Following this, he developed melena, then his appetite disappeared completely and he could no longer sleep. He died on the 60 th day of his illness. ${ }^{23 n, 24}$ This is, to nyy knowledge, the first description in the medical literature of Mediterranean anemia, which is currently attributed to Banti (1882). The melena described by 'Abũ al-Farräj also has been mentioned in Osler's description of Banti's discase. The hemiplegia, which seems to have improved, does not usually occur in Banti's disease; it may have been die to the newly described entity of disseminated intravascular coagulation (DIC) (Dr. Firzli). 'Abü al-Farrāj should then be credited with the first description of splenic anenia (Abü al Farraj's anemia) and the report of the first case of disseminated intravascular coagulation.

17) Ibn Jazlah mentions, in his "Taqwim al-Sihhah," for the first lime, the removal of a salivary stone from Stenson's duct. "One of the surgeons told me," he writes, "that he extracted, from the face of a man, a stone as big as siläh, possibly referring to a dermoid cyst, and that he ex- tracted from the back of the hand of another, a stone and that stones can grow to a large size and some huge ones can come out. I saw in the "al udi di" Hospital a stone that came out of a woman that weighed 15 "mithqaal"(about 66 grams); this was 3 days after its passage when it had dried. A reliable person told me that he had weighed it the day it was passed and found it to be 30 drachmas (about 92 grams)." ${ }^{14,34-7}$

18) Intestinal tuberculosis was described by ibn Zuhr.

19) Mediastinitis was described by ibn Zuhr.

20) In his section on diseases of the penis, ibn Zuhr writes: "Curvature of the penis can occur as a result of either an excess of dryness or a tumefaction." Ibn Zuhr mentions this entity 500 years before de La Peyronie (1643). ${ }^{17}$

21) Ibn Zuhr observed a case that he describes as follows: "Trauma to the abdomen can either heal or can be fatal. I have observed a man who defecated from an abdominal wound he had previously sustained; he survived for a long time, and was gainfully employed." This is a case of colo-cutaneous fistula. ${ }^{17}$

22) Pharyngeal paralysis also was described by ibn Zuhr.

\section{Contributions to Surgery}

Contributions to surgery during the Islamic Era include: The use of animal gut as a ligature in surgical operations and hot moist compresses to cover the exposed intestines during abdominal operations by al-Rãzi. ${ }^{20 b}$

The use of alcohol and cotton were popularized by al-Razzi who also advocated the operation of patellectomy in the treatment of certain patellar fractures. "The patella," writes al-Ràzi, "is more often the seat of contusions rather than fractures and comminutions. The diagnosis depends on the finding of roughness on palpation and gritting sound. Treatment is by reduction with extension or excision removal." This is the first mention in the medical literature of patellectomy in the treatment of patellar fractures. It precedes by over a thousand years the recent reintroduction of this procedure by Brooke in 1937. ${ }^{24,260.306}$

Al-Zahrāwi, who introduced the use of cotton in surgical dressings in the control of hemorrhage, as a padding in the splinting of fractures, as a vaginal packing in fractures of the pelvic bone, and in dentistry, ${ }^{310}$ also described the mastectomy for breast cancer, and thyroidectomy. He recommended and performed transverse tracheostomy as a life-saving procedure. He was also the first to suture traumatic wounds of the trachea. ${ }^{30}$. 31a He described Kocher's method of reducing dislocations of the hip, vaginal uretero-lithotomy, and lithotripsy.

About the latter he writes: "... the patient scratches his penis ... the rectum prolapses in many cases ... if the stone is small and incarcerated in the penile urethra thus preventing urinary flow, try before you resort to lithotomy, a method to be presently described and which I have tried. The method consists of using a sharp steel gimlet (drill) having a triangular shape as is shown in the illustration; 
the penis is tied with a thread proximal to the stone to prevent it from slipping back into the bladder; then the gimlet is very carefully introduced into the penis until it reaches the stone; the gimlet is then gently rotated by hand into the stone with the intention of drilling a hole into the slone; you keep drilling until the stone is pierced; the urine immediately flows and you can manually milk what remains of the stone, for it breaks into pieces and is washed out with the urine; and, God willing, the patient is cured." 38,39

Al-Zahraw made other numerous contributions to surgery including the use of giant ants ${ }^{40}$ for the closure of wounds of the intestinal gut, Trendelenburg's position, Waicher's position, and the extraction of a dead fetus with hooks. ${ }^{11}$

$\mathrm{Al}$-Zahrawi also gave the earliest description of the modern operation for varicose veins. ${ }^{\text {12" }}$ After the usual definitions and a description of the preoperative preparation, he describes the treatment of varicose veins by clot evacuation with the cautery and finally describes the surgical excision of varicose veins through multiple closely spaced small incisions in the following terms:

"The patient's leg is shaved if there is hair, then the patient is made to enter the bath of warm water. Compresses are applied to the leg until it becomes red ... then the skin is incised longitudinally over the varicose vein either at its lermination near the knee or at its origin near the ankle. The lips of the incision are opened with hooks. The vein is dissected from all sides until it is seen deep red in color; when it is free from the skin, it looks like a tendon. A probe is introduced beneath it so that when it is free from the skin it is held with a special blind smooth hook. Another skin incision is made three finger-breadths from the first incision; dissect the skin from the vein until it is free; raise the vein with probes as was done before and hold it with another hook as previously described. Do another incision and as many as necessary; then cut the vein in the last incision near the ankle and pull it out of the second incision and then pull it out of the incision above and so on until you reach the highest incision you pull the whole length of vein and excise it. One can also use a strong string and needle to help pull the vein. Apply on the incisions wool dipped in rose syrup and ointment or oil and treat until healing occurs." 396

This is 10 our knowlege, the first clear description of this modern procedure for the surgical excision of varicose veins.

Al-Zahrāwi also described more than 200 surgical instruments in the surgical part of his medical encyclopedia "al-Tașifli-man djoz un al-Ta'lif" (The Practice of Medicine for those who fall short of the Treatise). Almost all of these instruments were illustrated and many of them were of his own design. Recently, a Spanish historian actually made these instruments following the description of alZahrāwi and had the beautiful set exposed at the Tower Museum in Cordoba.
In dentistry, which was part of surgery, al-Zahrāwi described the first successful reimplantation of teeth. ${ }^{12 b}$

Two other contributions to surgery are worthy of menuon: the total hysterectomy by ibn Zuhr and urethral dilatation by al-Dhahabi. ${ }^{1 \mathrm{a}, 23 \mathrm{a}}$

\section{New Medications}

The following is a partial list of new medications introduced during the Islamic Era: alum, alloes, and antimony by ibn Mãsawih; mercurial ointment, lead ointment, certain trochisci (lozenges), for application to the eye by atRāzi. The latter became known as "Arab soap" or as "Trochiscus rhasis." The treatment of vitiligo with psomlen precursors was introduced by ibn al-Bitār. ${ }^{16}$

\section{New forms of therapy}

The following is a partial list of new forms of therapy introduced during the Islamic Era: nonmelallic urethral catheters (al-Rāzi) ${ }^{26 a}$; suggestion and autosuggestion in psychiatry (al-Tamimi); instillation of drugs in the urcthra (ibn Sinā ${ }^{43}$; the ice-cap in the treatment of brain conditions (ibn Sinā) ${ }^{43}$; the vaginal tampon (ibn Sināa) ${ }^{43}$; nutrient enema, gavage, contraceptive measures (ibn Zuhr) ${ }^{3}$; vaginal douching (ibn $\mathrm{Zuhr}$ ) $^{3}$, cotton in the treatment of uterine prolapse and nose fractures (ibn Zuhr) ${ }^{3}$; silk surures; and the diamond tip for the lithotrite (ibn Zuhr).

Music therapy and occupational therapy were highly developed in the hospitals. Special choirs and live music bands were brought daily to entertain the patients by providing singing performances on various instruments. There were also special story tellers, dancers and comic performers. $^{16}$

\section{Anesthesia}

Ibn Sina originated the idea of the use of oral

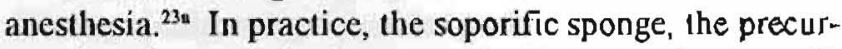
sor of modern anesthesia, was soaked in aromatics, soporifics, and narcotics and held to the patient's nose.

\section{Specialization and Specialties}

During the Islamic Era, several specializations became apparent, namely ophthalmology, pediatrics, and to some extent, urology.

\section{Optics and Ophthalmology}

The following are several contributions to ophthalmology:

- The first description of pannus in ophthalnia (ibn Mãsawih).

- Māsarjawì and Hunin ibn' Ishāq were the firsı physicians to have devoted special books to eye diseases.

- The description of the pupillary reflex to light (alRāzíi) ${ }^{26 \mathrm{~B}}$

The discovery that vision is the result of light being focused on the retina. 
- The insertion of the ocular muscles in the orbit of the eye (ibn Sinā).

- New methods and instruments for the treatment of lacrymal fistula such as the medicated probe (ibn Sina). ${ }^{41}$

\section{Pediatrics}

Al-Räzi was the first physician 10 have devoted a special book to diseases of children. ${ }^{\text {t* }}$

\section{Urology}

Ibn al-Jazzär devoted a monogram to urolithiasis. ${ }^{45}$

\section{Experimentation ${ }^{23 n}$}

Al-Ash'ath demonstrated gastric physiology on a live lion, which he had succeeded in dissecting. He poured water into its mouth to demonstrate to his students the distensibility and motility of the stomach, thus preceding Beaumont by about 1,000 years. ${ }^{6 \mathrm{~d}}$

Al-Räzi and al-Bïüni both experimented with the measurcment of specific gravity and devised simple and reliable instruments for that purpose. Al-Razi was the first to conceive and perform phamacological experiments on animals. After careful experimentation with various mercury compounds on monkeys, he introduced the use of mercurial purgatives. ${ }^{46}$

Ibn Zuhr has expressly expounded his views about the merit of observation and experimentation over the theoretical approach, which he calls "Safsatah." "Experimentation alone," he wrote, "can establish truths and demolish falsehoods"17 Trying to find out the prospects of tracheostomy, he performed experimental surgery on goats."

When ibn al-Mutrān was confronced with a patient who was bleeding from exposure to a plant that most probably contained some anticoagulant substance, he diligently experimented on animals by giving them the anticoagulant herb and tried several medications, one by one, until he found the right antidote. $23 x$

\section{Contagion and Congenital Cantagion}

The idea of contagion, especially in leprosy (Māsawih) and tuberculosis (ibn Sinā) was well known. It led to the insutution of quarantine measures. ${ }^{23 \text { A }}$ Congenital contagion was described by al-Räzi. ${ }^{36}$

\section{Medical Ethics}

The subject of ethics in general, and medical ethics in particular, was pursued during the Islamic Era on a grand scalc.

The story of Hunin ibn'Ishāģ's (Johannitus) willingness 10 go to prison rather than prescribe a lethal medicine muse have impressed thousands of physicians to whom Hunin's "Isagoge" was the introductory book to medicine. ${ }^{20}$

Three original additions to the Hippocratic Oath were made during the Islamic Era: ${ }^{20}$

a) The principle of defending one's colleagues was enunciated by al-Tabari. Here is an example:

Caliph Nāsir suffering from a vesical calculus, called his physician'Abū al-Khir, who failed to improve the caliph's condition; so Abũ Nașr, the author of al-'Iqtidāb, was called. The latter asked first to have the report of the treating physician (a rule of ethical conduct that is assumed to be of recent origin). He confirmed that the diagnosis was correct and the treatment was indicated. The caliph told him that the previous physician had made an error and was about to be condemned. 'Abü Nașr explained to the caliph that his colleague had not been mistaken and that the condition was taking its natural course. He pleaded with the caliph not to rant against physicians. ${ }^{\text {.* }}$

b) The principle of benevolent and free medical treatment, which was regarded as a duty and a moral satisfaction. ${ }^{48}$

c) The principle of continued medical education. AlBaghdādi wrote: "It is not enough to study a science, one has to continue to think about it, to discuss it with one's peers, to teach it and to write about it."18

The following story happened 700 years ago: "ibn alMutrān, the physician of Saladin, was once approached by one of his students who was looking for a job. Ibn alMutrān immediately introduced him to one of his patients, a prince, and outlined the treatment he needed. The prince was cured and the young physician cashed 5,000 dinars. The young man carried the money back to his teacher. The teacher returned it to him and introduced him to more of his patients. ${ }^{22 b}$ This story of voluntary referral and actual giving away of one's patient in favor of a colleague is in contrast to today's common practice of patient stealing and cut-throat competition. It is obvious that our present day mores have to travel a long way to become comparable to the mores of physicians of the Islamic Era.

\section{Medical Licensing}

We do have written evidence that, in the Islamic Era. physicians were examined for the purpose of obtaining a license to practice medicine. It is reported that Sinān was the official chief medical examiner at the time of the Caliph al-Muqtadir. In 931, he examined more than 860 physicians in Baghdad. The examination and licensing of physicians reached Europe 200 years later, through Sicily where it was introduced by Roger in $1140 .{ }^{23 a}$

\section{Contributions to Literary Form}

\section{Versification}

Poctry as a medical literary style and vehicle was introduced as a form that would make it easier for the students to remember. Ibn Sinā wrote a poem of medicine in 1326, verses that he entitled "al-Urjüzah fil-Tibb"; it was translated into Latin as the "Cantica" and was recently translated into French and into English. 'a 


\section{Illustration}

Medical illustrations were born in the Islamic Era The first examples were the famous eye diagrams of Hunin ibn Ishāq. These were followed by the illustrations of surgical instruments by al-Zahrāwi, the branches of physiology by al- Amshati and much later, the zoological illustrations of "al-Mustatraf" and the anatomy charts and the impotence rings of Mahäbādi.

\section{Tabulation}

Books in tabular form first appeared during the Islamic Era. In fact, a rare and fascinating quadruple event occurred in medical circles between c. 1050 and c 1150: the almost simultaneous appearance of four similar, yet different, Arabic medical books ("Taqwim al-Șihhăh," "Taqwim al-Abdan, al-Munjih, and Taqwim al-Adwiyah") written by four different physicians (ibn Butlan [c 1047], ibn Jazlah [d 1100], al-Alar'i [c 1151], and al-Tiflisi [c 1155], who lived in Cairo, Baghdad, Qonya, and Tiflis, respectively). ${ }^{35}$

In all four books, a new medical literary style, the tabular fonn, was used. The subject matter of the first two books is health; the last two is therapeutics. ${ }^{35}$

Al-Taflisi listed in his "Taqwim al-Adwiyah," 740 medications in alphabetical order giving their names in five different languages. Less than four centuries later, when printing started to become popular and when the Germans were beginning to replace their Latin scientific venue by the German language, the first book, "Taqwim al-Sihhah," by ibn Butlan (c 1047) was translated into German and was published in Strassburg in 1532; the second book, "Taqwim al'Abdān," by ibn Jazlah (d 1100) also was translated into German and published in Strassburg in 1533. In fact, these rwo books were two of the first medical books to be printed in Gernuan. ${ }^{22 \mathrm{a}, 35}$

\section{The Two-Way Translation Movement}

The most important contribution of the Islamic Era is, 10 my mind, what I have called "the two-way translation highway."

a) The first way was from Greek into Arabic. The Caliph al-M'amun was so fond of knowledge and science that he created especially for that purpose a special institution "Bit al-Hikmah" in Baghdad. This is where the school of translation was located. The translators included al-Kindi, Hunin ibn' Ishāq and his school. Hunin (792 or 809-873) can be justly considered the creator of the Arab renaissance by the excellence of his irreproachable translations, their importance, and their extent. He translated about 128 Greek medical books into Arabic. While doing so, he coined and forged innumerable Arabic medical words, terms, and expressions, most of which withstood the test of time to be used today. Leclerc wrote about him: "He is the greatest figure of the 9th century. He possessed one of the most beautiful personalities that one can ever meet in history" Al-M'amun was so enthusiastic about learning that he insisted on including a special clause in the peace treaty with the Byzantine emperor, which gave him the right to buy books in the Byzantine Empire. He was so avid of learning and books, that he was in the habit of recompensing the translator with the weight of the book in gold.

b) If one follows the other direction on my two-way highway, he finds the translation movement from Arabic into Latin. This movement was initiated by Constantin the African (d $1085 \mathrm{AD}),{ }^{13}$ the first translator of medical books from Arabic into Latin.

He was an Arab from Tunis. This movement culminated in the person of Gerardo di Cremona. Of these Latin translations of Arabic medical works, more than 71 books were printed. Out of them, 31 were printed more than once; Avicenna's Canon was printed 11 times in Latin. ${ }^{19}$ This translation movement afforded some medical education to the Europeans. Arabic medical books became widely distributed in Europe in easily obtainable Latin editions. It is this spread of learning from the Islamic Era that ignited the flame of the European Renaissance.

The influence of these contributions has continued to the present day. There are several Arabic terms that crept into the European languages, first into Latin and, subsequently, into French, Spanish, Italian, and English. A few examples are meri (esophagus) and siphac (peritoneum). In his recent dictionary, 'A bü Ghüsh lists 10,000 English words of Arabic origin. ${ }^{50}$ All of us know that alcohol, alkali, cotton, elixir, hakim, sugar, and syrup come from Arabic. A few other examples are acme, amalgam, amber, apricot, banana, benzoin, camphor, cough, cut, henna, massage, neck, oliban, saffron, saliva, sumac, tail, waist, and wrist.

\section{Survival in Syria and in India}

Original contributions of physicians during the Islamic Era not only survived in their Latin form in the European universities until the 18th century, but they also survived in the East. One example is Syria, where before the turn of this century and before the advent of medical graduates who started to come from Cairo in 1836, one could see practicing physicians using Avicenna's Canon; and referring to it frequently in their day-to-day practice. Avicenna's Canon had been printed in Rome in 1593 in an Arabic edition, which is so rare that it has become a collector's item.

The whole system has survived and today is a viable alternate to Western style medical care under various forms in different cultures. In the Indian subcontinent, for example, this system survives in what has been called Yünani medicine with its formal schools, its textbooks and all.

\section{Conclusion}

These were a few examples of original clinical descriptions and new therapeutic procedures gleaned from the available Arabic medical literature. They show that Arabic medical literature is replete with new original discoveries (not yet completely published), which are wrongly attributed 10 other more recent European authors. 
The observations made by the physicians of the Islamic Era concerning the clinical syndromes they described for the first time, were incisive and very clear. The new surgical procedures they described were founded on critical thinking and on experimentation. They also show conclusively that medicine during the Islamic Era was much more a science than anything else.

The Islamic Era constitutes the most fascinating chapter in the history of medicine. At the foundation of Islamic culture were two powerful pillars: intellectual curiosity and tolerance. During this era, two of the noblest tasks in history were accomplished: In the first, the physicians like bees, gathered the nectar from the various flowers of pre-Islamic medicine, whether Egyptian, Greek, or Indian, added to it their original contributions, and synthesized it into a homogeneous and delectable honey.

By 1100 . Islam had in place a complete, comprehensive, coherent and well organized system of medicine that included all the requisite elements: well-qualified physicians, more than 4,000 medical texts and encyclopedias, splendid free hospitals, renowned medical schools, pharmacies, a system of medical licensing, a system of medical ethics, and postgraduate medical training similar to our present-day residency system. A spirit of advanced benevolence, justice, and true social democracy permeated all these areas, without any discrimination against the poor and with absolute equality between the sexes and the colors.

Not only was this stupendous first task accomplished, but the second task, the translation of this corpus into Latin was started before 1085 . These contributions then were carried into darkened Europe, thus igniting the flame of the Renaissance.

We are only beginning to appreciate this enornous herilage and the tremendous impact of this brilliant civilization on the progress of human science in Europe during the Renaissance. There is much more research to be done in order to evaluate, at its true worth, the part Arabic texts played in the forward march of medicine.

\section{Recommendations}

In order to establish a basis for the continued study of the original contributions of physicians during the Islamic Era. I would like to formulate, in a schematic outline, three recommendations:

I Build up and publish three accurate lists of medical books:

1) Those known to have been written during the Islamic Era

2) Those that have survived, with their titles and their locations

3) Those that are available in print

a) in Arabic

b) in Latin

c) in modern languages

II Use these lists to choose the important medical books that should be published.

III Reform and revise the existing outdated International System of Transliteration. This system, which has been in use for several decades, falls short of our modern computer age requirements. It is just not compatible with the computer systems currently available. I propose that the International Institute of Islamic Medicine take upon itself this task and proceed, in cooperation with other international organizations, to initiate this necessary revision. I already have suggested a new system of transliteration, which is simple and computer friendly; my suggestion could be taken as a basis for discussion in order to arrive at a more thorough, practical, and definitive revised system of transliteration, which wouldbe acceptable to all parties concerned. $^{51}$

\section{References}

1a. Haddad, FS: Pioneers of Arabian medicine. Leb Med J 1968;21:67-80.

lb. Ibid.; 1968;21:343.

2a. Haddad, FS, Biesterfeldt, HH: Catalogue of the Arabic medical manuscripts in the Sami I Haddad Memorial Library. Aleppo: Aleppo University Press, 1984.

2b. Ibid.:11-43.

3. Ibn Zuhr: Al-Taysir. ed: M Khuri. Damascus: Dar alFikr, 1983.

4. Ibn al-Nadim: "Fihrist" (The index) 987.

5. Al-Qifí: Tarikh al-Hukama' (The history of the wise men/the physicians). 1227.

6a. Ibn 'Abi Ușaybi'ah: 'Uyūn al-Anbā' fĩ Țabaquāt al'Atibba' (The sources of information about the categories of physicians). Cairo: Wahhābiyyah Press, 1882.

6b. Ibid.:310.

6c. Ibid.:vol 1:163-4.

6d. Ibid:vol. 2: 142.

7. Häiji Khalïfah: Kashf-ul-Zunūn (Uncovering of the doubts). 1658.

8. Wüstenfeld: Geschichte der Arabischen Medizin

9. Leclerc, Lucien: Histoire de la Médecine Arabe 1876.

10. Brockelmann, C: Geschichte der Arabischen Literatur 1898.

11. Sarkis: Muajma 3 alma Tbuwoaat 1927.

12. Browne: Arabian medicine. 1921.

13. Campbell, D: Arabian Medicine, vol. 1. London: Kegan, 1926.

14. Ullmann, M: Die Medizin im Islam 1970.

15. Van Dyke: al-Iktifa (The Sufficient). 1897

16. Haddad, FS: The discovery and rediscovery of the treatment of vitiligo with psoralens. Acta Belg Hist Med 1989; 2:61-2.

17. Haddad, FS: Ibn Zuhr's contributions to surgery. Leb Med J 1994;42:41-5.

18. Haddad, FS: Ibn Zuhr (Avenzoar) (1091-1162). Leb

Med J 1993;41:249-55.

19. Haddad, FS: Ibn Zuhr (Avenzoar) (1091-1162). Act 
Belg Hist Med 1991;4:135-46.

20. Haddad, FS: Arab medical ethics. Studies in Hist Med 1982; Jun:122-36.

21. Haddad, FS: Arab medicine and sociely. MEJ Anesth 1974; 4:87-108.

22a. Haddad, SI: History of Arab medicine. ed.: FS Haddad. Beirut: Bouheiry Bros., 1975:74.

22b. Tbid.:65.

23a. Haddad, FS: Arab contribution to medicine. Leb med J 1973;26:331-46.

23b. Haddad, FS: Arab contribution to medicine. Leb med J 1973;26:22-5.

24. Haddad, FS: Clinical sketches from Arab medicine. Presented at the $24 \mathrm{th}$ International Congress of the History of Mcdicine, Budapest 1974. Published in the proceedings, 1976;2:1359-65.

25. Haddad, FS: Arab andrology and sexology. Presented at the 30th International Congress of the History of Medicine, Dusseldorf, September 1986. Published in the Actes (Proccedings, Leverkusen, Vicom) 1988;1253-64.

26a. Haddad, FS: Arab contribution to medicine. Leb med J 1973;26:331-46.

26b. Ibid.; $13: 210,218$.

27. Al-Razi: Al-Häwi (The Continens) manuscript in Sami I Haddad Memorial Library (Orient Hospital). p. 216.

28a. Al-Razi: Al-Hăwi (The Continens). vols. 10,13,16 Hyderabad: Osmania, 1961-63. 1237 v, ff270v.

28b. Ibid.: vol. 13, p. 18 .

29. Thorek, M: Human testicle. Philadelphia: Lippincott, 1924P. 488Note.

30a. Haddad, FS: al-Zahrāwì. Leb Med J 1966;19:29.

30b. Haddad, FS, Haddad, SI: Historical review in Patellectomy in the treatment of fracture of the Patella. Ann Repon Orient Hosp. 1950;3:48-49.

3la. Haddad, FS: Abulcasis. Abbotempo 1968:8.

3lb. Ibid.;1968:73.

3lc. lbid.;1968:25.

32a. Haddad, FS: al-Zahrāwi, the great Arab surgeon. Presented at the 21 st Congress of the History of Medicine, Siena, Sept. Published in the proceedings. 1968. 1970:16007.

32b. Ingram, GIC: Blood factor VIII. Adv Clin Chem 1965;8:207.

33. Bulloch, W, Fildes, P: Hemophilia, in: Treasury of human inheritance, Calton, Laboratory for National Eugenics. Cambridge: Cambridge University Press, 1911.

34. Ton Jazlah: Taqwim-al-Abdān, manuscript in the author's library, copied 994 A.H.

35. Haddad, FS: Arab tetralogy of medical texts in tabular form (in press).
36. Haddad, SI: Ma'athir al-Arab fil-'Ulūm al-tibbiyyah: Contributions of the Arabs to the medical sciences. Beirut: Rīhāni Press, 1936. 61-2.

37. Haddad, SI: Ma'āthir al-Arab fil-'Ulūm al-jirāhiyyyah (Contributions of the Arabs to the surgical sicences). Ann Rep Orient Hosp 1981;14:84.

38. Haddad, FS: Calculi of the penile urethra. Ann Rep Orient Hospital 1965;18:16.

39a. Al-Zahrāwí: "al-Taşrif liman 'Ajaz'an 'al-Ta'lif." Photocopy of the Channing edition, Oxford: 1778. in Sami I Haddad Memorial Library of the Orient Hospital, and MS in Damascus National Museum. p.286-8.

39b. Ibid.:434-8.

40. Haddad, FS: Sutures, ligatures, ants and slaples. I Islam Med Assn. 1994;26:83-4.

41. Fadel, HE: Obstetrics in Islamic medicine: A historial perspective. J Islam Med Assn. 1996;28:103-8.

42a. Summer JE: Highlights in treatment of varicose veins and ulcers. Am J Surg 1953;86:443-63.

42b. Haddad, FS: Reimplantation of teeth (al-Zahrawi). J Kurwait Med Ass. 1967;1:328.

43. Gruner OC: A treatise on the Canon of medicine of Avicenna. London: Luzac, 1930. p. 27.

44. Elgood C: Medical history of Persia. Cambridge: Cambridge University Press, 1957. p. 54.

45. Haddad, FS: "Kitāb ibn al-Jazzär fill-hasạa:" (Ibn alJazzär's monograph on Urolithiasis) presented at ibn alJazzär's millenium in Tunis, 1984 and published in Colloque International de Tunis, Millénaire d'ibn al-Jazzar, 1987. pp. 293-305.

46. Cumston: An introduction to the history of medicine. London, 1926.

47. Haddad, FS: Surgical firsts in Arabic medical literature. Studies in Hist Med 1986-7. 10-11:95-103.

48. Haddad, FS: Les principes déontologiques dans la médecine Arabe. Presented at the 22nd International Congress of the History of Medicine, Bucarest 1970. Published in the proceedings, 1972:67-8.

49. Haddad, FS: Latin translations of Arabic medical texts that went through more than one edition. Proceedings of the 32nd International Congress of the History of Medicine, Antwerp 1990. ER Fierens, ed. pp.697-706.

50. 'Abū Güsh, S: 'Asharat 'Āläf Kalimah inkliziyyah min 'așl 'Arabi ('Ten thousand English words of Arabic origin). Kuwait: al-Marzüq, 1977.

51. Haddad, FS: New simple transliteration system (in press). 